\title{
Aktivitas Antiparkinson Ekstrak Rimpang Temulawak (Curcuma Xathorriza Roxb.) Pada Tikus Putih (Rattus Norvegicus) Galur Sprague Dawley Yang Diinduksi Haloperidol
}

\section{Antiparkinson Activity Temulawak Rhizome Extract (Curcuma Xathorriza Roxb.) In White Rats (Rattus Norvegicus) Sprague Dawley Range Haloperidol-Induced}

\author{
Nofika Dwi Anitasari ${ }^{1}$, Jason Merari Peranginangin ${ }^{1}$, Sri Rejeki Handayani ${ }^{1}$ \\ ${ }^{1}$ Fakultas Farmasi Universitas Setia Budi \\ Jl. Let. Jen. Sutoyo, Mojosongo-Solo Indonesia \\ anitasrinofikadwi@gmail.com
}

\begin{abstract}
ABSTRAK
Temulawak (Curcuma xathorriza Roxb.) merupakan tanaman yang mengandung kurkumin. Kurkumin dalam ekstrak etanol rimpang temulawak telah terbukti dapat menembus sawar darah otak dan memiliki efek neuroprotektif sehingga dapat mengurangi gejala parkinson yang diakibatkan oleh haloperidol. Penelitian ini bertujuan mengetahui aktivitas ekstrak etanol rimpang temulawak dalam mengurangi gejala parkinson dan mengetahui dosis efektif ekstrak rimpang temulawak dalam mengurangi gejala parkinson.

Penelitian ini menggunakan 35 ekor tikus yang terbagi menjadi 7 kelompok, masingmasing kelompok terdiri dari 5 ekor tikus. Kelompok 1 diberi aquadestilata (kontrol sehat). Kelompok II diberi larutan CMC-Na 0,5\% p.o (kontrol negatif). Kelompok III diberi larutan levodopa dosis $27 \mathrm{mg} / \mathrm{kgbb}$ (kontrol positif). Kelompok IV diberi larutan vitamin E dosis 180 IU/kgbb (kontrol positif). Kelompok V, VI, VII diberi ekstrak temulawak berturut-turut 120, 240 dan $480 \mathrm{mg} / \mathrm{kgbb} .45$ menit kemudian semua kelompok kecuali kelompok I diberi haloperidol 2 $\mathrm{mg} / \mathrm{kgbb}$ i.p. Uji catalepsy dan rota rod dilakukan pada hari ke 0, 4, 7,11 dan ke 14 .

Dari uji catalepsy ekstrak temulawak dosis 120, 240, $480 \mathrm{mg} / \mathrm{kgbb}$ berturut-turut menunjukkan aktivitas penurunan katalepsi sebesar 23,25; 52,28 dan 58,56 \%. Sedangkan pada uji rota rod menunjukkan aktivitas peningkatan waktu latensi berturut-turut sebesar 26,87; 30,34 dan $34,58 \%$. Dosis efektif ekstrak rimpang temulawak dalam mengurangi gejala parkinson adalah dosis $240 \mathrm{mg} / \mathrm{kgbb}$.
\end{abstract}

Kata kunci: temulawak, curcuma, kurkumin, catalepsy, rota rod.

\section{ABSTRACT}

Temulawak (Curcuma xathorriza Roxb.) Is a plant that contains curcumin. Curcumin in ethanol extracts of temulawak rhizome has been shown to penetrate the blood brain barrier and has a neuroprotective effect that can reduce the symptoms of parkinsonism caused by haloperidol. This study aims to determine the activity of ethanol extract of temulawak rhizome in reducing symptoms of Parkinson's and know the effective dose of temulawak rhizome extract in reducing symptoms of Parkinson's.

This study used 35 rats divided into 7 groups, each group consisting of 5 rats. Group 1 was given aquadestilata. Group II was given a solution of $0.5 \%$ CMC-Na p.o. Group III was given levodopa dose $27 \mathrm{mg} / \mathrm{kgbb}$. Group IV was given vitamin E dose of $180 \mathrm{IU} / \mathrm{kgbb}$. Groups V, VI, VII were given the temulawak extracts of 120, 240 and $480 \mathrm{mg} / \mathrm{kgbb}$. 45 minutes later all groups except group I were given haloperidol $2 \mathrm{mg} / \mathrm{kgbb}$ i.p. The catalepsy and rota rod tests were performed on days $0,4,7,11$ and 14 .

From catalepsy test of temulawak extract dose $120,240,480 \mathrm{mg} / \mathrm{kgbb}$ respectively showed activity of catalepsy decrease equal to 23,$25 ; 52,28$ and $58,56 \%$. While in rota rod test shows the activity increase time of latency consecutively equal to 26,$87 ; 30,34$ and $34,58 \%$. The effective dose of temulawak rhizome extract in reducing symptoms of Parkinson's is a dose of $240 \mathrm{mg} / \mathrm{kgbb}$.

Keywords: temulawak, curcuma, kurkumin, catalepsy, rota rod. 


\section{PENDAHULUAN}

Penyakit Parkinson adalah gangguan sistem saraf pusat, yang melibatkan degenerasi sel-sel saraf tertentu di bagian otak yang disebut ganglia basal, dan juga hilangnya sel-sel saraf (neuron) tertentu di bagian batang otak yang disebut substansia nigra. Selsel ini memproduksi neurokimia dopamin, yang berperan merangkai pesan untuk mengkoordinasikan gerakan normal. Hilangnya (substansial lebih dari $80 \%$ dari tingkat normal) dopamin, menyebabkan neuron di daerah penerima (disebut reseptor dopamin) di bagian striatum tidak cukup dirangsang, sehingga terjadilah gangguan gerakan dengan gejala tremor, kelambatan, kekakuan, keseimbangan (Golbe et al. 2009). Kerusakan sel saraf dopaminergik dapat dipicu oleh penuaan dan adanya stress oksidatif (Hwang 2013). Radikal bebas, bahan kimia yang diproduksi sebagai produk sampingan dari reaksi kimia normal tubuh, terutama pembuatan dopamin. Dalam sel-sel otak pasien parkinson, terdapat radikal bebas melebihi normal dan terjadi oksidasi yang berlebihan. Oksidasi menyebabkan kerusakan pada sel-sel otak dopamin (Golbe et al. 2009).

Mekanisme kerja obat antipsikotik tipikal seperti haloperidol dan chlorpromazin adalah memblokade dopamin pada reseptor pasca sinaptik neuron di otak, khususnya di sistem limbik dan sistem ekstrapiramidal (Dopamin D2 reseptor antagonists) (Maslim 2003). Berdasarkan penelitian Reinke A. (2004), menunjukkan bahwa haloperidol dan clozapin dapat menyebabkan stres oksidatif sel-sel di striatum dan hippocampus pada tikus. Haloperidol dapat meningkatkan MDA, oksida nitrat dan penurunan $\mathrm{GSH}$ di beberapa daerah otak, serta terjadi penurunan glutathione seluler di daerah tertentu di otak (otak kecil, striatum dan korteks) selain itu haloperidol juga menyebabkan penurunan signifikan ATP dan energi dalam sel-sel di otak (Vairetti et al. 1999). Dengan adanya mekanisme kerja tersebut maka penggunaan haloperidol mempunyai potensi yang besar untuk menimbulkan efek samping diantaranya berupa gejala ekstrapiramidal.

Menurut Nurcholis (2012) temulawak terdapat senyawa kurkuminoid yang diketahui mempunyai aktivitas antioksidan. Secara khusus, kurkumin telah terbukti mengurangi kerusakan oksidatif dan patologi amiloid pada dimensia alzheimer (Frautschy et al. 2001). Kurkumin dalam ekstrak etanol rimpang temulawak dapat menembus sawar darah otak (Smart 2006) dan memilik efek neuroprotektif berupa antioksidan (Chattopaday et. Al. 2004). Sehingga dapat mencegah kerusakan sel saraf dopaminergik akibat stres oksidatif.

Penelitian ini bertujuan mengetahui efek ekstrak rimpang temulawak dalam mengurangi terjadinya gejala parkinson pada tikus putih galur Sparague dawley yang diinduksi haloperidol.

\section{METODE PENELITIAN}

Alat yang digunakan dalam pembuatan serbuk rimpang temulawak adalah pisau, oven, mesin giling, dan ayakan ukuran 40 mesh. Alat yang digunakan dalam pembuatan ekstrak 
rimpang temulawak adalah botol gelap, kain flanel, timbangan analitik, alat-alat gelas, rotary evaporator. Alat yang digunakan untuk uji kandungan serbuk dan ekstrak adalah serangkaian alat sterling bidwel, moisture balance, mafel, gelas porcelin, tabung reaksi, alat uji KLT. Pada uji antiparkinson digunakan alat catalepsy bar test dan alat rota rod test.

Bahan yang digunakan dalam penelitian ini adalah rimpang temulawak yang diperoleh dari daerah Takeran, Magetan Jawa Timur, pelarut etanol 96 $\%$, tikus putih jantan galur sprague dawley dengan berat 100-180 g. Fase diam silika gel $60 \mathrm{~F} 254$, fase gerak $n$ heksan P-etilasetat (1:1), xylen, haloperidol, levodopa, vitamin E, CMC $\mathrm{Na}$, aquadest

Pembuatan ekstrak, Rimpang temulawak segar dicuci kemudian diirissetebal 7-8 $\mathrm{mm}$ kemudian di oven pada suhu $50^{\circ} \mathrm{C}$ hingga kering. Simplisia kering digiling dan diayak dengan ayakan mesh 40. Serbuk simplisia diuji kadar airnya. Sebanyak 1200 mg serbuk kering rimpang temulawak direndam menggunakan pelarut etanol $96 \%$ sebanyak $1200 \mathrm{ml}$ selama 6 hari. Proses ekstraksi dilakukan secara maserasi dengan metode remaserasi. Maserat disaring dan sari etanol dipekatkan dengan rotary evaporator. Ekstrak yang diperoleh diidentifikasi kandungannya. Identifikasi kandungan kurkumin dari ekstrak rimpang temulawak dilakukan secara KLT dengan fase diam silika gel $60 \mathrm{~F}_{254}$, fase gerak $n$-heksan $P$-etilasetat (1:1) dan dibandingkan dengan baku kurkumin $0,1 \%$.

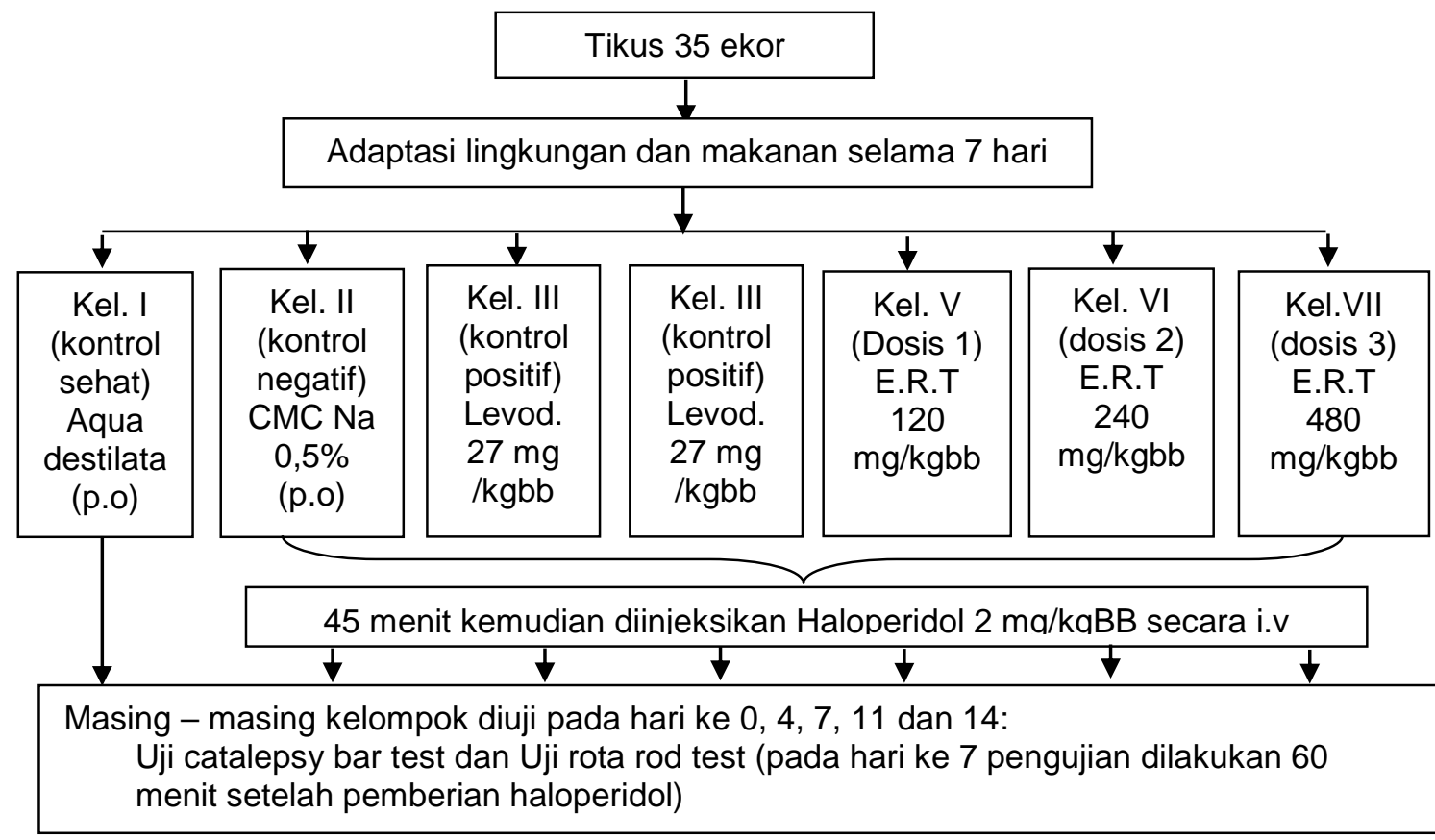

Gambar 1. Skema uji antiparkinson

E.R.T : Ekstrak Rimpang Temulawak

Levod. : Levodopa 


\section{Uji Catalepsy bar}

Tes dilakukan dengan metode yang dijelaskan oleh Balsara, Jadhav \& Chandorkar 1980, menggunakan hewan uji dengan berat 100-180 gram, katalepsi diukur menggunakan tes bar standar, waktu hewan mempertahankan posisi dengan kedua kaki depan diangkat dan beristirahat di kayu bar (diameter $0,7 \mathrm{~cm}$ ) dan tinggi $8 \mathrm{~cm}$ di atas permukaan. Titik akhir katalepsi terjadi ketika kedua kaki depan telah berpindah posisi dari bar atau jika posisi kepala hewan pindah dengan cara eksplorasi. Waktu yang digunakan untuk pengukuran katalepsi maksimal 180 detik. Lama waktu hewan uji mempertahankan posisinya dinyatakan dalam skor (Sanberg PR et al. 1988), semakin besar skor, semakin buruk.

Tabel 1. Skor katalepsi

\begin{tabular}{ll}
\hline Lama waktu & Skor \\
\hline $0-10$ detik & 0 \\
$10-30$ detik & 1 \\
$30-60$ detik & 2 \\
$60-120$ detik & 3 \\
$120-180$ detik & 4 \\
$\infty 180$ detik & 5 \\
\hline
\end{tabular}

\section{Uji rota rod}

Metode rota rod dilakukan dengan cara hewan uji ditempatkan pada silender horizontal dimana kecepatan putarannya berakselerasi dari 4 sampai 40 rpm dengan maksimal waktu pengamatan 300 detik. Percobaan dimulai ketika akselerasi dimulai dan berakhir ketika hewan uji jatuh dari batang horizontal. Waktu laten (waktu hewan uji bertahan pada silinder berputar hingga terjatuh) serta kecepatan rod ketika tikus jatuh dari alat rod tersebut dicatat. Hewan yang normal dapat menjaga keseimbangan dalam waktu yang tidak terbatas walaupun dilakukan akselerasi kecepatan. Penurunan gerakan ditunjukkan oleh ketidakmampuan hewan untuk bertahan pada roller selama masa uji 300 detik dengan akselerasi kecepatan (Mouzon B et. al. 2012)

\section{Analisis Data}

Skor katalepsi dan waktu latensi dianalisis menggunakan uji Kolmogorv Smirnorv untuk mengetahui data terdistribusi normal atau tidak. Dilanjutkan dengan uji one way anova dilihat homogenitasnya, jika data homogen (sig.>0,05) dilanjutkan dengan uji Tukey, namun jika data tidak homogen (sig.<0,05) dilanjutkan dengan uji Tamhane.

\section{HASIL DAN PEMBAHASAN Hasil Pembuatan Ekstrak}

Pembuatan ekstrak rimpang temulawak dilakukan di laboratorium Fitokimia Universitas Setia Budi. Diperoleh ekstrak rimpang temulawak sebesar 41,44 gram atau 3,45\%. Identifikasi kurkumin dengan cara KLT menghasilkan nilai $\mathrm{Rf}$ ekstrak rimpang temulawak sebesar $0,50 \mathrm{~cm}$ dan nilai $\mathrm{Rf}$ baku kurkumin sebesar $0,46 \mathrm{~cm}$. Hasil menunjukkan nilai Rf ekstrak rimpang temulawak dengan nilai $\mathrm{Rf}$ baku kurkumin hampir sama, artinya ekstrak rimpang temulawak mengandung kurkumin.

\section{Hasil Uji Farmakologi}

Hewan uji sebanyak 35 ekor yang dibagi menjadi 7 kelompok. Hewan uji diadaptasi terlebih dahulu selama $7 \pm$ hari agar terhindar dari stres. 


\section{Hasil Uji "Catalepsy Bar”}

Hasil pengujian Catalepsy Bar dapat dilihat pada tabel 2.

Tabel 2. Skor rata-rata katalepsi dari masing-masing kelompok perlakuan

\begin{tabular}{|c|c|c|c|c|c|}
\hline KEL. & & & HARI & & \\
\hline UJI & $\mathbf{0}$ & 4 & 7 & 11 & 14 \\
\hline I & $0,00 \pm 0,00$ & $0,00 \pm 0,00$ & $0,00 \pm 0,00$ & $0.00 \pm 0.00$ & $0,00 \pm 0,00$ \\
\hline II & $0,00 \pm 0,00$ & $4,20 \pm 0,45^{\mathrm{a} *}$ & $4,60 \pm 0,89^{a}$ & $4,00 \pm 0,00^{\mathrm{a}}$ & $4,20 \pm 4,45^{\text {a e }}$ \\
\hline III & $0,00 \pm 0,00$ & $2,00 \pm 0,00^{\mathrm{b} *}$ & $3,00 \pm 0,71^{\mathrm{a} *}$ & $1,00 \pm 0,71^{\mathrm{b}} *$ & $0,60 \pm 0,55^{b}$ \\
\hline IV & $0,00 \pm 0,00$ & $2,00 \pm 1,00^{a}$ & $2,40 \pm 0,55^{\text {a } *}$ & $1,20 \pm 0,45^{b *}$ & $0,60 \pm 0,55$ be \\
\hline V & $0,00 \pm 0,00$ & $3,00 \pm 0,00^{a}$ & $4,20 \pm 0,45^{a d}$ & $3,00 \pm 0,00^{d}$ & $2,20 \pm 0,45^{b d}$ \\
\hline VI & $0,00 \pm 0,00$ & $2,40 \pm 0,55^{\mathrm{a} b} *$ & $2,60 \pm 0,55^{\mathrm{a} e *}$ & $1,60 \pm 0,55^{b}$ & $0,80 \pm 0,45^{\text {b e }}$ \\
\hline VII & $0,00 \pm 0,00$ & $1,80 \pm 0,45^{\text {a b } *}$ & $2,60 \pm 0,55^{\mathrm{ae}}$ & $1,40 \pm 0,55^{b}$ & $0,60 \pm 0,55^{\mathrm{be}}$ \\
\hline
\end{tabular}

Keterangan :

I : kelompok kontrol sehat

II : kelompok kontrol negatif

III : kelompok kontrol positif levodopa

IV : kelompok kontrol positif vitamin E

$\mathrm{V} \quad$ : kelompok dosis I ERT $120 \mathrm{mg} / \mathrm{kgbb}$

VI : kelompok dosis II ERT 240

$\mathrm{mg} / \mathrm{kgbb}$

VII : kelompok dosis III ERT 480 $\mathrm{mg} / \mathrm{kgbb}$

Berbeda signifikan dengan :

a : berbeda signifikan terhadap kontrol sehat $(p<0,05)$

Berdasarkan data tabel 2 dapat dilihat pada hari ke 0 skor katalepsi dari masing-masing hewan uji masih 0 . Yang artinya hewan uji masih dalam keadaan sehat belum menunjukkan gejala parkinson, karena belum diinduksi haloperidol.

Pada hari ke 4 menunjukkan peningkatan skor katalepsi disemua kelompok hewan uji, kecuali kelompok sehat. Pada kelompok kontrol negatif menunjukkan perbedaan yang signifikan dibanding hari ke 0 , hal ini menandakan induksi haloperidol berhasil. Pada kelompok levodopa, vitamin E, dosis ekstrak rimpang temulawak 120, 240, $480 \mathrm{mg} / \mathrm{kgbb}$ menunjukkan peningkatan skor katalepsi namun tidak sebanyak kelompok negatif. terdapat beda b : berbeda signifikan terhadap kontrol negatif $(p<0,05)$

$c$ : berbeda signifikan terhadap kontrol positif levodopa $(p<0,05)$

$\mathrm{d}$ : berbeda signifikan terhadap kontrol positif vitamin $E(p<0,05)$

e : berbeda signifikan terhadap dosis 1 ( $p<$ $0,05)$

* : berbeda signifikan terhadap hari sebelumnya $(p<0,05)$.

ERT : Ekstrak Rimpang Temulawak

signifikan antara kelompok negatif, dengan kelompok sehat, kontrol positif levodopa dan vitamin E serta kelompok dosis ekstrak rimpang temulawak. Pada hari ke 7 , semua kelompok menunjukkan peningkatan skor, karena pada hari ke 4 dan 7 hewan uji masih diinduksi haloperidol.

Pada hari ke 11 semua kelompok mengalami penurunan skor katalepsi. Karena pada mulai hari ke 8 hewan uji sudah tidak diberi induksi haloperidol. namun pada kelompok kontrol negatif tidak meunjukkan perbedaan signifikan dengan hari sebelumnya, walaupun mengalami penurunan skor katalepsi. Sedangkan pada kelompok kontrol positif levodopa, vitamin E dan ekstrak rimpang temulawak dosis 120, 240 dan 
$480 \mathrm{mg} / \mathrm{kgbb}$ mengalami penurunan katalepsi terdapat beda signifikan dengan kelompok negatif.

Pada hari ke 14, kelompok kontrol positif levodopa, vitamin E, dosis ekstrak rimpang temulawak berbeda signifikan dengan kontrol negatif. hal ini menunjukkan jika kelompok kontrol positif levodopa, vitamin E, dosis ekstrak rimpang temulawak mengalami penurunan terjadinya gejala katalepsi. memperbaiki postur tubuh hewan uji timbul dikarenakan pada hari ke 4 dan 7 hewan uji masih diinduksi haloperidol sehingga pengujian terjadi saat kadar puncak haloperidol masih tinggi dalam plasma. Kadar puncak Haloperidol dalam plasma tercapai dalam waktu 2-6 jam sejak obat diminum (Israr YA 2009). Selain itu haloperidol dan beberapa neuroleptik atipikal misalnya, clozapine, olanzapine, dan risperidone dapat menyebabkan gangguan pada fungsi

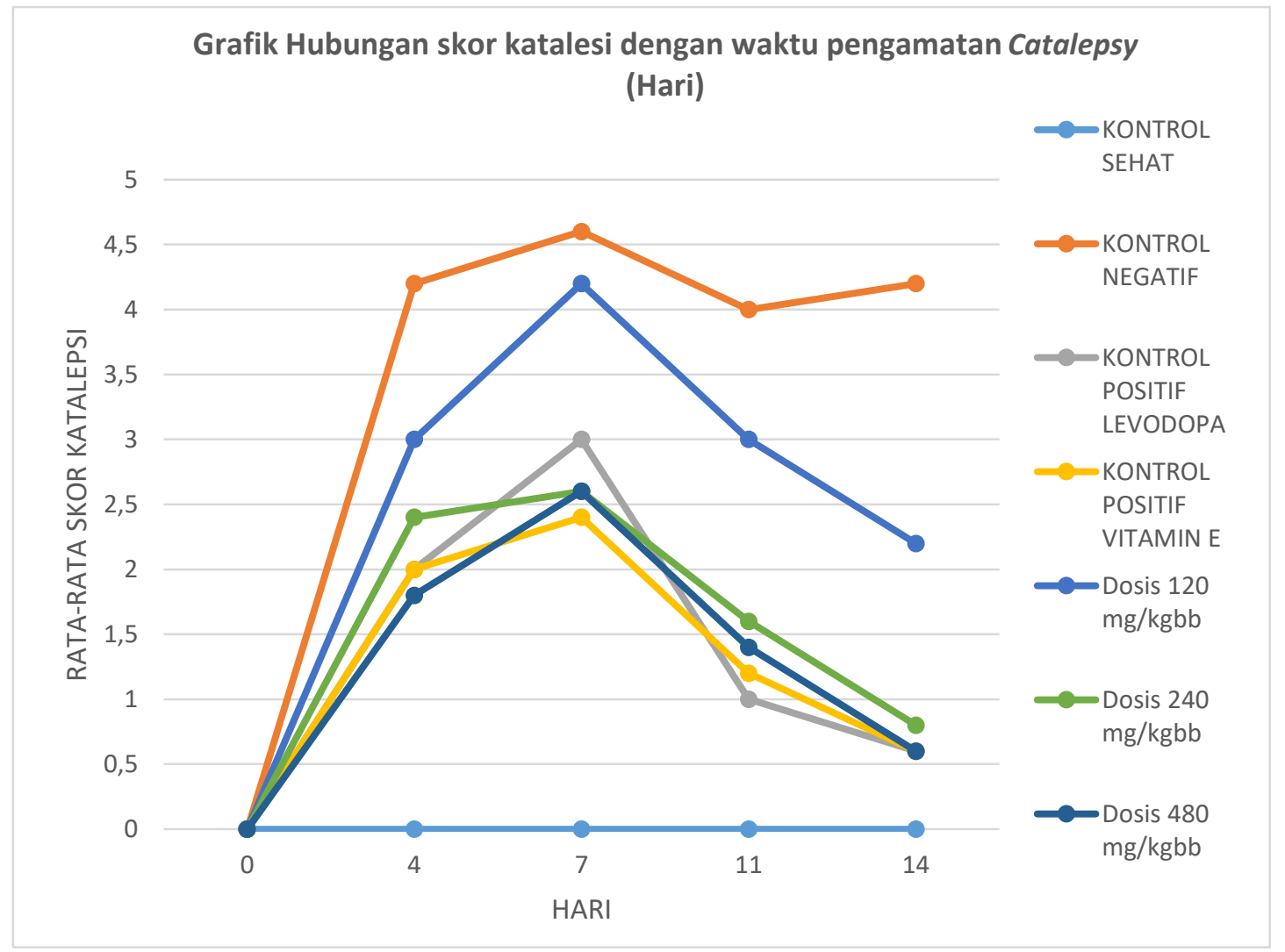

Gambar 2. Hubungan skor katalepsi dengan waktu pengamatan Catalepsy (hari)

Berdasarkan grafik diatas, dapat diketaui pada hari ke 4 dan 7 , semua kelompok menunjukkan peningkatan skor katalepsi. Kemungkinan efek kekakuan otot dan gangguan dalam kerja ketika diberikan 30 menit sebelum pengujian (Skarsfeldt 1996). Namun pada kelompok kontrol positif levodopa, vitamin $\mathrm{E}$ dan ekstrak rimpang temulawak dosis 120, 240 dan 480 $\mathrm{mg} / \mathrm{kgbb}$ peningkatan skor katalepsi tidak sebesar kontrol negatif. 
Pada hari ke 11 dan 14 kelompok kontrol negatif tidak menunjukkan penurunan skor katalepsi yag berarti. $\mathrm{Hal}$ ini Hal ini menandakan jika hewan uji pada kontrol negatif tidak menunjukkan kondisi yang membaik walaupun penginduksian haloperidol sudah dihentikan pada hari ke 7 . Kemungkinan efek katalepsi yang terjadi diakibatkan oleh efek haloperidol yang dapat menyebabkan stres oksidatif sel-sel di striatum dan hippocampus pada tikus (Reinke A. 2004). Haloperidol dapat meningkatkan MDA, oksida nitrat dan penurunan GSH dibeberapa daerah otak, serta terjadi penurunan glutathione seluler di daerah tertentu di otak (otak kecil, striatum dan korteks) dan dalam hati selain itu Haloperidol juga dapat menyebabkan penurunan yang signifikan ATP dan energi dalam sel-sel di otak (Vairetti et al. 1999). Karena efek tersebut menyebabkan kerusakan sel-sel saraf otak yang memproduksi dopamin. Sehingga kadar dopamin dalam otak tidak mencukupi.

Namun pada kelompok kontrol positif levodopa, vitamin $\mathrm{E}$ dan ekstrak rimpang temulawak dosis $120,240,480$ $\mathrm{mg} / \mathrm{kgbb}$ menunjukkan penurunana skor katalepsi. Hal ini dikarenakan levodopa dapat memulinkan neurotransmisi dopaminergik pada korpus striatum dengan cara meningkatkan sintesis dopamin pada neuron yang masih bertahan di substansia nigra. Pada pasien yang masih berada di stadium awal penyakit, jumlah neuron dopaminergik yang tersisa dalam substansia nigra (biasanya sekitar 20\% dari normal) sudah cukup untuk mengkonversikan levodopa menjadi dopamine (Harvey \& Champe 2013). Dengan adanya sifat antioksidan dari vitamin $E$, sel dan komponen tubuh yang lain akan terlindungi dari serangan radikal bebas dan menghentikan reaksi berantai atau oksidasi merusak. Selain itu vitamin $E$ akan mencegah kerusakan DNA, mempertahankan LDL, dan unsur tubuh yang kaya lemak untuk melawan oksidasi (Farris MW \& Zhang JG 2003). Begitu juga pada ekstrak rimpang temulawak ekstrak temulawak dapat melindungi sel-sel otak dari kerusakan akibat stres oksidatif akibat haloperidol. Kurkumin dalam ekstrak etanol rimpang temulawak memiliki efek neuroprotektif dari aktivitas antioksidan yang dimiliki (Chattopaday et al. 2004) sehingga dapat mencegah kerusakan sel saraf dopaminergik akibat stres oksidatif.

Untuk menghitung aktivitas penurunan katalepsi dimasing-masing kelompok kontrol positif levodopa, vitamin $E$ dan ekstrak rimpang temulawak dosis 120,240, $480 \mathrm{mg} / \mathrm{kgbb}$ digunakan metode pehitungan AUC.

$$
A U C_{t n-1}^{t n}=\frac{K_{t n-1+} K_{t n}}{2}{ }_{x}\left(t_{n}-t_{n-1}\right)
$$

Keterangan :

$t n=$ hari ke $\mathrm{n}$

$K_{t n}=$ Skor katalepsi pada hari ke $\mathrm{n}$

$\%$ penurunan Katalepsi $=$

$$
\frac{A U C_{k n}-A U C_{u j i}}{A U C_{K n}} \times 100 \%
$$

Keterangan :

$A U C_{k n}=A \cup C$ total kontrol negatif $A U C_{u j i}=\mathrm{AUC}$ total kelompok uji 
Tabel 3. Hasil \% penurunan katalepsi tikus

\begin{tabular}{ccc}
\hline & $\begin{array}{c}\text { Rata-rata } \\
\text { AUC total } \pm \\
\text { Kel. }\end{array}$ & $\begin{array}{c}\text { \% penurunan } \\
\text { katalepsi } \pm \text { SD }\end{array}$ \\
\hline III & $21,90 \pm 4,93$ & $56,42 \pm 13,48$ \\
IV & $20,50 \pm 6,85$ & $59,88 \pm 12,80$ \\
V & $39,00 \pm 1,54$ & $23,25 \pm 7,47^{*}$ \\
VI & $24,30 \pm 1,75$ & $52,28 \pm 4,00$ \\
VI & $21,20 \pm 5,32$ & $58,56 \pm 9,37$ \\
\hline
\end{tabular}

Keterangan :

* : berbeda signifikan dengan kontrol positif levodopa, kontrol positif vitamin E, dosis 2 dan dosis $3(p<0,05)$

I : kelompok kontrol sehat

II : kelompok kontrol negatif (haloperidol 2 $\mathrm{mg} / \mathrm{kgbb}$ )

III : kelompok kontrol positif levodopa (27 $\mathrm{mg} / \mathrm{kgbb})$

IV : kelompok kontrol positif vitamin $\mathrm{E}$

$\mathrm{V}$ : kelompok dosis I ERT $120 \mathrm{mg} / \mathrm{kgbb}$

$\mathrm{VI}$ : kelompok dosis II ERT $240 \mathrm{mg} / \mathrm{kgbb}$

VII : kelompok dosis III ERT $480 \mathrm{mg} / \mathrm{kgbb}$

ERT : Ekstrak Rimpang Termulawak

Berdasarkan data tabel 3, dapat diketahui kelompok kontrol positif levodopa, vitamin E, dosis 120, 240 dan $480 \mathrm{mg} / \mathrm{kgbb}$ ekstrak rimpang temulawak memiliki aktivitas menurunkan gejala parkinson berupa katalepsi pada hewan uji. Selain itu terdapat perbedaan yang signifikan $(p<0,05)$ antara kelompok dosis ekstrak rimpang temulawak $120 \mathrm{mg} / \mathrm{kgbb}$ dengan kelompok kontrol positif levodopa, vitamin $\mathrm{E}$ dan dosis ekstrak rimpang temulawak 240, $480 \mathrm{mg} / \mathrm{kgbb}$. Hal ini menunjukkan jika dosis ekstrak rimpang temulawak $120 \mathrm{mg} / \mathrm{kgbb}$ memiliki aktivitas yang paling kecil. Persen penurunan katalepsi paling besar pada vitamin $\mathrm{E}$ sebesar 59,88 \%. Dengan adanya sifat antioksidan dari vitamin $\mathrm{E}$, sel dan komponen tubuh yang lain akan terlindungi dari serangan radikal bebas dan menghentikan reaksi berantai. Selain itu vitamin E akan mencegah kerusakan DNA yang menyebabkan mutasi, mempertahankan LDL, dan unsur tubuh yang kaya lemak melawan oksidasi (Farris MW \& Zhang JG 2003).

Selanjutnya kelompok dosis yang memiliki aktivitas penurunan katalepsi paling besar setelah vitamin $\mathrm{E}$ adalah dosis ekstrak rimpang temulawak 480 $\mathrm{mg} / \mathrm{kgbb}$ sebesar 58,56 \%. Temulawak (Curcuma xanthorrhiza Roxb) terdapat senyawa kurkuminoid yang diketahui mempunyai aktivitas antioksidan. Kurkumin secara signifikan dapat menghambat reaktif spesies oksigen (ROS) seperti anion superoksida, $\mathrm{H}_{2} \mathrm{O}_{2}$ dan radikal nitrit. Kurkumin dalam ekstrak etanol rimpang temulawak dapat menembus sawar darah otak (Smart 2006) dan memiliki efek neuroprotektif dari aktivitas antioksidan yang dimiliki (Chattopaday et al. 2004) sehingga dapat mencegah kerusakan sel saraf dopaminergik akibat stres oksidatif.

\section{Hasil Uji "Rota Rod"}

Data hasil uji rota rod berupa waktu latensi yaitu waktu yang dibutuhkan hewan uji untuk mempertahankan dirinya di batang rota rod hingga terjatuh.semakin lama waktu latensi menunjukkan hewan uji memiliki koordinasi keseimbangan yang baik. Data waktu latensi hewan uji dapat dilihat pada tabel 3 . 
Tabel 3. Rata-rata \pm SD waktu latensi uji rata rod

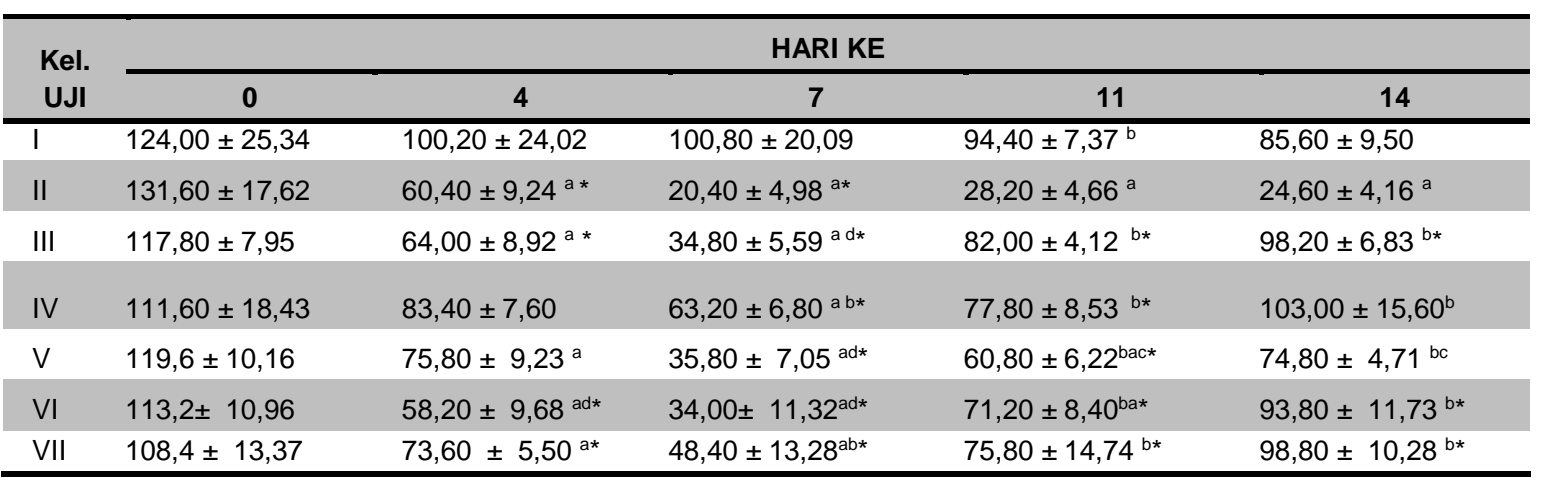

Keterangan :

I : kelompok kontrol sehat

II : kelompok kontrol negatif

III : kelompok kontrol positif levodopa

IV : kelompok kontrol positif vitamin E

$\mathrm{V} \quad$ : kelompok dosis I ERT $120 \mathrm{mg} / \mathrm{kgbb}$

VI :kelompokdosis II ERT $240 \mathrm{mg} / \mathrm{kgbb}$

VII : kelompok dosis III ERT 480 $\mathrm{mg} / \mathrm{kgbb}$

Berbeda sognifikan dengan :

sebelumnya $(p<0,05)$

ERT : Ekstrak Rimpang Temulawak

Berdasarkan data tabel 3, dapat diketahui jika pada hari ke 0 disemua kelompok tidak terdapat perbedaan yang signifikan waktu latensi. Hal ini menandakan belum adanya gejala gangguan keseimbangan koordinasi motorik pada hewan uji.

Pada hari ke 4 dan 7 terjadi penurunan waktu latensi pada semua kelompok. Hal ini menandakan induksi haloperidol telah berefek, hal ini ditunjukkan oleh adanya perbedaan yang signifikan antara hari ke 4 dengan hari ke 0 dan hari ke 7 dengan hari ke 0 . Penurunan waktu latensi paling banyak terdapat pada kelompok kontrol negatif. sedangkan pada kelompok kontrol positif levodopa, vitamin E, dan ekatrak rimpang temulawak dosis 120, 240 dan a : berbeda signifikan terhadap kontrol sehat $(p<0,05)$

b : berbeda signifikan terhadap kontrol negatif $(p<0,05)$

$c$ : berbeda signifikan terhadap kontrol positif levodopa $(p<0,05)$

$\mathrm{d}$ : berbeda signifikan terhadap kontrol positif vitamin $E(p<0,05)$

e : berbeda signifikan terhadap dosis 1 ( $p<$ $0,05)$

* : berbeda signifikan dengan hari

$480 \mathrm{mg} / \mathrm{kgbb}$ menunjukkan penurunan waktu latensi tidak sebanyak kontrol negatif.

Pada hari ke 11 dan 14, kelompok kontrol negatif tidak menunjukkan peningkatan waktu latensi hal ini ditunjukkan tidak terdapat perbedaan signifikan antara waktu latensi hari ke 11 dengan hari ke 7 dan hari ke 14 dengan hari ke 11. Sedangkan pada kelompok kontrol positif levodopa, vitamin E dan ekstrak rimpang temulawak dosis 120 , 240 dan $480 \mathrm{mg} / \mathrm{kgbb}$ menunjukkan peningkatan waktu latensi. $\mathrm{Hal}$ ini ditunjukkan terdapat beda signifikan dimasing-masing kelompok tersebut pada hari ke 11 dan 14 dengan hari sebelumnya. 


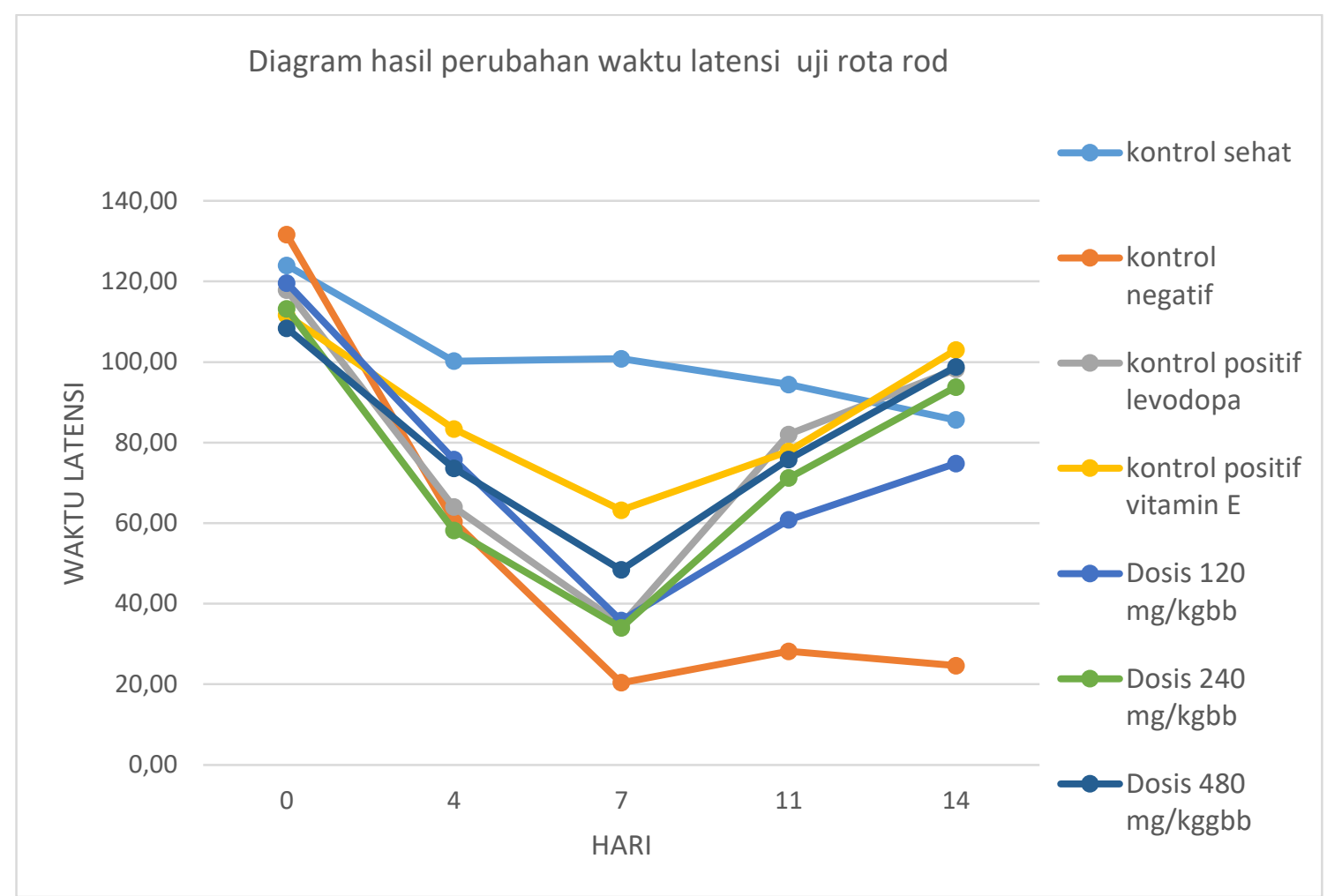

Gambar 2. hasil perubahan waktu latensi uji rota rod

Berdasarkan gambar 2, dapat diketahui pada hari ke 4 dan 7 semua kelompok kecuali kelompok sehat mengalami penurunan waktu latensi. Penurunan paling besar terjadi pada kelompok kontrol negatif. Hal ini dikarnakan hewan uji pada kelompok ini tidak diberi levodopa, vitamin $\mathrm{E}$ ataupun ekstrak. Sedangkan pada kelompok kontrol positif levodopa, vitamin E dan dosis ekstrak temulawak waktu latensi juga mengalami penurunan namun berbeda signifikan $(p<0,05)$ dibanding kontrol negatif. Penurunan ini dikarenakan pada hari ke 4 dan 7 hewan uji masih diinduksi haloperidol sehingga pengujian terjadi saat kadar puncak haloperidol masih tinggi dalam plasma. Kadar puncak Haloperidol dalam plasma tercapai dalam waktu 2-6 jam sejak obat diminum, menetap sampai 72 jam dan masih dapat ditemukan dalam plasma sampai berminggu-minggu (Israr YA 2009).

Pada hari ke 11 dan 14 kelompok kontrol negatif mengalami penurunan waktu latensi, hal ini dikarenakan haloperidol selain memblokade dopamin pada reseptor pasca sinaptik neuron di otak, khususnya di sistem limbik dan sistem ekstrapiramidal (Dopamin D2 reseptor antagonists) (Maslim 2003), berdasarkan penelitian Reinke $A$. (2004), menunjukkan bahwa haloperidol dapat menyebabkan stres oksidatif sel-sel di striatum dan hippocampus pada tikus, yang dapat memicu rusaknya sel-sel otak.

Sedangkan pada hari ke 11 dan 14 dari kelompok kontrol positif levodopa, vitamin E, dan ketiga dosis ekstrak temulawak mengalami kenaikan waktu latensi. Hal ini 
$\begin{array}{lr}\text { dikarenakan } & \text { levodopa dapat } \\ \text { memulihkan } & \text { neurotransmisi }\end{array}$ dopaminergik pada korpus striatum dengan cara meningkatkan sintesis dopamin pada neuron yang masih bertahan di substansia nigra. Pada pasien yang masih berada di stadium awal penyakit, jumlah neuron dopaminergik yang tersisa dalam substansia nigra (biasanya sekitar $20 \%$ dari normal) sudah cukup untuk mengkonversikan levodopa menjadi dopamine (Harvey \& Champe 2013). Sedangkan vitamin E memiliki sifat antioksidan, yang dapat melindungi selsel otak dari serangan radikal bebas dan menghentikan reaksi berantai atau oksidasi merusak. Selain itu vitamin $\mathrm{E}$ akan mencegah kerusakan DNA yang menyebabkan mutasi, mempertahankan HDL, dan unsur tubuh yang kaya lemak melawan oksidasi (Farris MW \& Zhang JG 2003). Dan Kurkumin dalam ekstrak etanol rimpang temulawak dapat menembus sawar darah otak (Smart 2006) dan memiliki efek neuroprotektif dari aktivitas antioksidan yang dimiliki (Chattopaday et al. 2004) sehingga dapat mencegah kerusakan sel saraf dopaminergik akibat stres oksidatif. Untuk menghitung aktivitas peningkatan waktu latensi dimasingmasing kelompok kontrol positif levodopa, vitamin dan ekstrak rimpang temulawak dosis 120,240, 480 $\mathrm{mg} / \mathrm{kgBB}$ digunakan metode pehitungan AUC.

$$
A U C_{t n-1}^{t n}=\frac{L_{t n-1+} L_{t n}}{2} \times\left(t_{n-t_{n-1}}\right)
$$

Keterangan :

$t n=$ hari ke $\mathrm{n}$

$L_{t n}=$ waktu latensi pada hari ke $\mathrm{n}$

$$
\begin{gathered}
\% \text { kenaikan waktu latensi }= \\
\frac{A U C_{u j i}-A U C_{K n}}{A U C_{u j i}} \times 100 \%
\end{gathered}
$$

Keterangan :

$A U C_{k n}=$ AUC total kontrol negatif

$A U C_{u j i}=\mathrm{AUC}$ total kelompok uji

Tabel 4. Peningkatan persen waktu latensi

\begin{tabular}{lcc}
\hline Kel. & AUC total & $\begin{array}{c}\% \text { Kenaikan } \\
\text { waktu latensi }\end{array}$ \\
\hline III & $1015 \pm 75,65$ & $32,50 \pm 8,08$ \\
IV & $1163,10 \pm 135,83$ & $40,49 \pm 10,25$ \\
V & $954,80 \pm 64,37$ & $26,87 \pm 5,46$ \\
VI & $981,10 \pm 71,92$ & $30,34 \pm 6,35$ \\
VII & $1057,30 \pm 143,61$ & $34,58 \pm 10,48$ \\
\hline
\end{tabular}

Keterangan :

III : kelompok kontrol positif levodopa $27 \mathrm{mg} / \mathrm{kgbb}$

IV : kelompok kontrol positif vitamin E $180 \mathrm{IU} / \mathrm{kgbb}$

$\mathrm{V} \quad$ : kelompok dosis I ERT $120 \mathrm{mg} / \mathrm{kgbb}$

VI : : kelompok dosis II ERT $240 \mathrm{mg} / \mathrm{kgbb}$

VII : kelompok dosis III ERT 480 $\mathrm{mg} / \mathrm{kgbb}$

ERT : Ekstrak Rimpang Temulawak

Berdasarkan tabel 4, dapat diketahui kontrol positif levodopa, vitamin $E$, dosis 120, 240 dan 480 $\mathrm{mg} / \mathrm{kgbb}$ ERT memiliki aktivitas menurunkan gejala parkinson berupa gangguang koordinasi dan keseimbangan pada hewan uji. Dan tidak terdapat perbedaan signifikan dmasing-masing kelompok kontrol positif levodopa, vitamin $\mathrm{E}$ dan dosis 120,240, $480 \mathrm{mg} / \mathrm{kgbb}$ ERT.

Vitamin E memiliki aktivitas peningkatan waktu latensi paling besar dibanding kelompok lain. Sedangkan Ekstrak Rimpang temulawak dosis III (480 mg/kgbb) menunjukkan aktivitas peningkatan waktu latensi kedua terbesar setelah vitamin $\mathrm{E}$.

Dosis efektif merupakan dosis terkecil yang mampu memberikan efek yang tidak berbeda signifikan $(p>0,05)$ 
dengan kontrol positif pada dua uji Catalepsi bar test dan rota rod test, dosis efektif ekstrak rimpang temulawak dalam mengurangi terjadinya gejala parkinson yaitu dosis $240 \mathrm{mg} / \mathrm{kgBB}$. Karena pada dosis ekstrak rimpang temulawak 240 $\mathrm{mg} / \mathrm{kgbb}$ merupakan dosis terkecil yang mampu mengurangi gejala parkinson berupa penurunan katalepsi pada uji catalepsi bar test dan peningkatan waktu latensi pada uji rota rod yang tidak berbeda signifikan $(p<0,05)$ dengan konrol positif levodopa dan viamin E.

\section{KESIMPULAN}

Dari uji catalepsy ekstrak rimpang temulawak dosis 120, 240, $480 \mathrm{mg} / \mathrm{kgbb}$ berturut-turut menunjukkan aktivitas penurunan katalepsi sebesar 23,25; 52,28 dan $58,56 \%$. Sedangkan pada uji rota rod menunjukkan aktivitas peningkatan waktu latensi berturut-turut sebesar 26,87; 30,34 dan 33,19\%. Dosis ekstrak rimpang temulawak yang efektif dalam mengurangi tejadinya gejala parkinson yaitu dosis 240 $\mathrm{mg} / \mathrm{kgbb}$.

\section{DAFTAR PUSTAKA}

Chattopadhyay I. et al. 2004. Turmeric and curcumin: Biological actions and medicinal applications.

Golbe LI, et al. 2010. The Parkinson's disease. Mov. Disord.16:442447.

Hwang Onyou. 2013. Role of Oxidative Stress in Parkinson's Disease 31.

Israr YA. et al. 2009. Obat Anti Mania. Pekanbaru. Files of DrsMed - FK UNRI.
Maslim R. 2001. Diagnosis Gangguan Jiwa, Rujukan Ringkas PPDGJ-III. Jakarta: FK-Atmajaya.

Mouzon B, et. al. 2012. Repetitive mild traumatic brain injury in a mouse model produces learning and memory deficits accompanied by histological changes. Pub-Med 29(18):2761-73.

Nurcholis W, et al. 2012. Curcuminoid Contents, Antioxidant and Antilnflammatory Activities of Curcuma xanthorrhiza Roxb. and Curcuma domestica Val. Promising Lines From Sukabumi of Indonesia. Prosiding Seminar Nasional Kimia Unesa, 284-292.

Reinke A, Martins MR, Lima MS, Moreira JC, Dal-Pizzol F, Quevedo J (2004). Haloperidol and clozapine, but not olanzapine, induces oxidative stress in rat brain. Neuroscience Letters 372 , 157-160.

Sanberg, PR et. al. 1988. The Catalepsy Test: Its Ups and Downs. American Psychological Association, Inc. 102, No. 5, 748759.

Smart J. 2006. Curcumin: A Powerful Brain Protection Supplement, Available from: URL: http://accelerating.org/articles/cur cumin. Html.

Vairetti M, et al. 1999. Haloperidolinduced changes in glutathione and energy metabolism: effect of nicergoline. Eur $J$ Pharmacol $1999 ; 367: 6$ 
